\title{
The Potential Effect of Circadian Rhythms and Lighting Duration on Behavior and Growth Performance of Quails under Egyptian Condition Hesham H. Mohammed
}

Veterinary Public Health Department, Faculty of Veterinary Medicine, Zagazig University, 44511, Egypt

\begin{abstract}
The aim of this study was to observe and record the changes in behaviors and performance of Japanese quails "Coturnix japonica" due to circadian rhythms and different light duration. A total of 220 Japanese quail chicks were used and distributed to two experiments (the circadian rhythms (100 birds) and the lighting duration study (120 birds). The behaviors were recorded by direct observation and video recording. The results showed significant differences in the most recorded behaviors among the different day times, especially in video recording. The ingestive and kinetic behaviors were significantly higher at morning, while the resting behavior was the highest in mid-day. Comfort behavior was significantly lower at morning than other times. The light duration had significant effects on ingestive and kinetic behaviors. It was highest in 24 hours of light duration. While, the dust-bathing was significantly higher in 14 (2.9) than 24 hours of light duration (1.74). Quails growth performance did not reveal significant differences between quails kept in 14 and 24 hours of light duration. It was concluded that, the quails on different day times and lighting duration showed significant difference on the normal behavior.
\end{abstract}

Keywords: Quail, Behavior, Lighting Duration, Circadian Rhythms.

\section{Introduction}

Japanese quails were inexpensive to keep, where it reared in small cages and had high immunity against the common poultry diseases. Although, it represents a form of poultry production, but it is more nervous than other poultry species. They able to fly in vertical position to upwards. The adult male and female quail weighed about 100-140 and $120-160 \mathrm{~g}$, respectively. Most of organisms have a clock in their brain that regulates the timing of biological processes and daily behavior, which known as circadian rhythms [1]. Most of the maintenance processes and behaviors were related to 24 hour day/night cycle. Behavioral studies are crucial not only for increasing knowledge of animal status, but also for assessing the animal's response to its environment that consequently impaired its welfare [2]. Welfare assessment may provide a feedback or information to be considered during the management and when designing poultry houses [3]. The most important factor affecting all diurnal rhythms is the light cycle, where the light acts as time keeper controlling the circadian rhythms [4]. Quails have excellent full-color vision and can see under ultraviolet lighting due to their higher sensitivity to the wave length [5].

Photoperiodism (light duration or day length) underlies the so-called biological calendar [6]. The light duration was widely used for improving the reproductive performances of layers [7]. Furthermore, Classen et al. [8], founded that lighting duration had significant effects on production and welfare of broilers. To our knowledge, only a few experiments were conducted to assess the role of the light duration and diurnal rhythm on quail behavior. Hence, our study was designed to record the changes in behaviors of Japanese quails due to the light duration and circadian rhythm.

\section{Material and Methods}

\section{Experiment one}

One hundred Japanese quail chicks were obtained from commercial hatchery, housed in the same home pen and distributed into five groups (20 birds for each). The floor space for each group were $1 \mathrm{~m}^{2}$, providing each quail with $0.05 \mathrm{~m}^{2}$ of floor space with bedding materials of sawdust $(10 \mathrm{~cm}$ thickness $)$. The brooding temperature monitored at $35^{\circ} \mathrm{C}$ during the $1^{\text {st }}$ brooding week and then decreased $3.5^{\circ} \mathrm{C}$ weekly until full feathering of quails. The diet ingredients for the current study mentioned in Table (1), as recommended by AOAC [9]. Feed and water were provided ad-libitum. 
Table 1: Composition of the experimental diet $(\mathrm{kg} / 100 \mathrm{~kg})$

\begin{tabular}{lllc}
\hline Ingredient & Kg & Calculated composition & $24.9 \%$ \\
\hline Yellow corn & 56.10 & Crude protein & $3.45 \%$ \\
Soybean meal & 32.73 & Crude fiber & $3909 \mathrm{MJ} / \mathrm{kg}$ \\
Fish meal & 5.50 & Metabolized energy & $1.23 \%$ \\
Other feed additives & 1.9 & Calcium \& Phosphorus & \\
\hline
\end{tabular}

The focal sample technique [10] was used for recording quail's behaviors through direct observation after quails identification at the $2^{\text {nd }}$ week of age. Moreover, scan sampling technique [11] was also done after applying the cameras and additional light in all groups for video recording. Behavioral observations (Table 2) were performed as the following: each group was observed for 4 consecutive days at 3 different periods per day with focal technique (morning: from 9:00 a.m. to 12:00 p.m.; afternoon: from 12:00 p.m. to 3:00 p.m. and late afternoon: from 3:00 p.m. to 6:00 p.m.) and 4 different periods/day with scan technique (morning: from 9:00 a.m. to 12:00 p.m.; afternoon: from 12:00 p.m. to 3:00 p.m.; late afternoon: from 3:00 p.m. to 6:00 p.m. and evening: from 6 p.m. to 9 p.m.). In focal technique, the behavioral patterns in all groups were recorded by the observer who standing in front of the groups after waiting for five minutes before recording for acclimatization [5]. Quail's numbers were counted for calculating behavior percentage after scanning technique.

Statistical analysis was done using the analysis of variance (one way ANOVA) through the SAS statistical system [12], where the results were presented as Mean \pm Standard Error with significance at $\mathrm{P}<0.05$.

Table 2: Definition of recorded behaviors*

\begin{tabular}{|c|c|}
\hline Observed behavior & Definition \\
\hline Ingestive behavior & Eating: number of quails on troughs; Drinking: number of quails on drinkers. \\
\hline $\begin{array}{l}\text { Kinetic behavior } \\
\text { Litter scratching }\end{array}$ & $\begin{array}{l}\text { Walking: either walk or run; Flying: number of flying in a box. } \\
\text { Number of scratching by the toes of legs in the litter. }\end{array}$ \\
\hline $\begin{array}{l}\text { Resting behavior } \\
\text { a. Crouching } \\
\text { b. Huddling }\end{array}$ & $\begin{array}{l}\text { laying or sitting breast on the floor with closed eyes. } \\
\text { When three or more quails are overlapped a crouching position in an allelomimetic } \\
\text { pattern. }\end{array}$ \\
\hline $\begin{array}{l}\text { c. Sitting } \\
\text { d. Idling } \\
\text { Comfort behavior } \\
\text { a. Feather preening }\end{array}$ & $\begin{array}{l}\text { Lying on one side. } \\
\text { Standing without activity. }\end{array}$ \\
\hline $\begin{array}{l}\text { b. Dust bathing } \\
\text { Abnormal behavior }\end{array}$ & $\begin{array}{l}\text { Number of bathing in litter. } \\
\text { Aggression: the birds counteracts of others; Feather pecking: pecks to feathered } \\
\text { parts. }\end{array}$ \\
\hline
\end{tabular}

*Based on Mohammed et al. [2].

\section{Experiment two}

A total of 120 one-day old Japanese quail chicks were kept in new constructed pens (2 $\mathrm{m}^{2}$ ) and distributed into two experimental groups of 14 and 24 hours of light duration of incandescent light (each 60 quails). Each group was divided into three replicates (each of 20 birds). Husbandry condition and management were as in experiment one. The behavioral patterns were observed and recorded as in experiment one by scan sampling technique. Moreover, all growth performance (initial body weight, final body weight, average body weight gain, daily body weight gain, daily feed intake and feed conversion ratio) were calculated [2]. The data were analyzed using Student's t-test by SAS program [12].

\section{Results}

The activity of quails (flying behavior) was the highest in the morning, while the resting behaviors (crouching, huddling, sitting and 
idling) were higher at noon (Table 3). There were significant effects of diurnal times on all normal behaviors of Japanese quails (Table 4).
While, abnormal behaviors (feather pecking and aggression) were numerically differed among the experimental groups.

Table 3: Mean time ( \pm SE) / 2 hour weekly for normal and abnormal behaviors of Japanese quail "Coturnix japonica" in different day times under Egyptian condition using the focal sampling technique

\begin{tabular}{lcccc}
\hline \multirow{2}{*}{ Behavior } & \multicolumn{4}{c}{ Day times } \\
\cline { 2 - 5 } & Morning & Noon & Afternoon & $\mathbf{P}^{1}$ \\
\hline Feeding & $9.13 \pm 0.82$ & $7.53 \pm 1.09$ & $8.00 \pm 1.28$ & 0.324 \\
Drinking & $3.47 \pm 0.69$ & $2.60 \pm 0.54$ & $3.00 \pm 0.62$ & 0.854 \\
Walking & $3.38 \pm 0.83$ & $2.39 \pm 0.58$ & $3.33 \pm 0.23$ & 0.831 \\
Flying & $6.00 \pm 0.24^{\mathrm{a}}$ & $3.49 \pm 0.21^{\mathrm{b}}$ & $1.30 \pm 0.09^{\mathrm{c}}$ & 0.021 \\
Litter scratching & $4.27 \pm 1.06$ & $3.49 \pm 1.25$ & $4.88 \pm 1.15$ & 0.532 \\
Crouching & $2.66 \pm 0.62^{\mathrm{c}}$ & $8.09 \pm 0.36^{\mathrm{a}}$ & $5.20 \pm 0.35^{\mathrm{b}}$ & 0.041 \\
Huddling & $7.67 \pm 1.08^{\mathrm{b}}$ & $11.18 \pm 1.74^{\mathrm{a}}$ & $9.70 \pm 1.64^{\mathrm{ab}}$ & 0.011 \\
Sitting & $4.13 \pm 1.65^{\mathrm{b}}$ & $11.53 \pm 1.07^{\mathrm{a}}$ & $9.80 \pm 0.98^{\mathrm{ab}}$ & 0.029 \\
Idling & $4.71 \pm 1.44^{\mathrm{b}}$ & $8.96 \pm 1.21^{\mathrm{a}}$ & $6.51 \pm 1.77^{\mathrm{ab}}$ & 0.031 \\
Feather preening & $2.53 \pm 0.62$ & $2.00 \pm 0.57$ & $3.73 \pm 0.97$ & 0.378 \\
Dust bathing & $4.80 \pm 1.04$ & $4.13 \pm 0.62$ & $5.07 \pm 0.74$ & 0.178 \\
Feather pecking & $1.87 \pm 0.89$ & $1.75 \pm 0.89$ & $1.91 \pm 0.04$ & 0.385 \\
Aggression & $0.67 \pm 0.01$ & $0.13 \pm 0.09$ & $0.93 \pm 0.08$ & 0.771 \\
\hline
\end{tabular}

${ }^{1} \mathrm{P}$ : Probability (2-tailed). ${ }^{\text {ab }}$ Means within the same row having different superscripts were significantly different $(\mathrm{P} \leq$ 0.05 and $\mathrm{P} \leq 0.01)$.

Quails reared in $24 \mathrm{~h}$ light duration were the highest in eating and drinking behaviors Moreover, they were more active (walking and flying behaviors). The frequency of dust bathing was significantly higher in $14 \mathrm{~h}$ of light duration than in $24 \mathrm{~h}$. The other behaviors and growth performance did not reveal significant differences between the two groups (Table 5).

Table 4: Means of normal and abnormal behaviors in Japanese quail kept under different circadian rhymes (\% of hens in observation period) using scan sampling technique

\begin{tabular}{lccccc}
\hline \multicolumn{5}{c}{ Day Times } \\
\hline Behavior & Morning & Noon & Afternoon & Evening & $\mathbf{P}^{1}$ \\
\hline Feeding & $8.06 \pm 1.04^{\mathrm{a}}$ & $2.43 \pm 0.27^{\mathrm{b}}$ & $2.69 \pm 0.26^{\mathrm{b}}$ & $4.62 \pm 1.13^{\mathrm{b}}$ & $>0.001$ \\
Drinking & $5.40 \pm 0.79^{\mathrm{a}}$ & $2.37 \pm 0.37^{\mathrm{b}}$ & $4.11 \pm 1.12^{\mathrm{ab}}$ & $2.19 \pm 0.38^{\mathrm{b}}$ & 0.009 \\
Walking & $2.17 \pm 0.15^{\mathrm{a}}$ & $0.17 \pm 0.02^{\mathrm{b}}$ & $0.21 \pm 0.11^{\mathrm{b}}$ & $1.93 \pm 0.11^{\mathrm{ab}}$ & $>0.001$ \\
Flying & $10.35 \pm 1.27^{\mathrm{a}}$ & $2.15 \pm 0.27^{\mathrm{c}}$ & $1.75 \pm 0.12^{\mathrm{c}}$ & $6.92 \pm 1.52^{\mathrm{b}}$ & $>0.001$ \\
Litter scratching & $5.27 \pm 0.73^{\mathrm{a}}$ & $2.36 \pm 0.39^{\mathrm{b}}$ & $4.10 \pm 1.12^{\mathrm{ab}}$ & $2.16 \pm 0.42^{\mathrm{b}}$ & 0.011 \\
Crouching & $2.17 \pm 0.38^{\mathrm{c}}$ & $4.69 \pm 1.10^{\mathrm{b}}$ & $6.85 \pm 0.91^{\mathrm{a}}$ & $2.35 \pm 0.30^{\mathrm{c}}$ & $>0.001$ \\
Huddling & $0.17 \pm 0.11^{\mathrm{b}}$ & $2.06 \pm 0.21^{\mathrm{a}}$ & $1.81 \pm 0.09^{\mathrm{a}}$ & $0.23 \pm 0.10^{\mathrm{b}}$ & $>0.001$ \\
Sitting & $1.67 \pm 0.13^{\mathrm{b}}$ & $8.56 \pm 1.24^{\mathrm{a}}$ & $9.65 \pm 1.10^{\mathrm{a}}$ & $1.72 \pm 0.24^{\mathrm{b}}$ & $>0.001$ \\
Idling & $0.25 \pm 0.08^{\mathrm{c}}$ & $1.75 \pm 0.49^{\mathrm{b}}$ & $7.79 \pm 1.07^{\mathrm{a}}$ & $0.82 \pm 0.12^{\mathrm{b}}$ & $>0.001$ \\
Feather preening & $0.95 \pm 0.48^{\mathrm{b}}$ & $3.95 \pm 0.66^{\mathrm{a}}$ & $3.86 \pm 0.62^{\mathrm{a}}$ & $3.21 \pm 0.36^{\mathrm{a}}$ & 0.001 \\
Dust bathing & $0.25 \pm 0.17^{\mathrm{b}}$ & $4.27 \pm 0.45^{\mathrm{a}}$ & $4.24 \pm 0.37^{\mathrm{a}}$ & $3.77 \pm 0.42^{\mathrm{a}}$ & $>0.001$ \\
Feather pecking & $0.08 \pm 0.02^{\mathrm{a}}$ & $0.00 \pm 0.00$ & $0.2 \pm 0.05$ & $0.07 \pm 0.03$ & 0.584 \\
Aggression & $0.09 \pm 0.01^{\mathrm{a}}$ & $0.00 \pm 0.00$ & $0.15 \pm 0.05$ & $0.06 \pm 0.01$ & 0.577 \\
\hline
\end{tabular}

${ }^{\mathrm{P}} \mathrm{P}$ : Probability (2-tailed). ${ }^{\mathrm{ab}}$ Means within the same row having different superscripts were significantly different $(\mathrm{P} \leq$ 0.05 and $\mathrm{P} \leq 0.01)$.

\section{Discussion}

The behavior represents a series of activities of endocrine or exocrine character [13] for assessing the animal's response to its environment that consequently affects its welfare. Circadian rhythms are the most important factor that affects the behavior of the birds which controlled by mean of endogenous diurnal clock [1]. In the present study changes in behaviors of quail chicks by circadian rhythms and lighting duration were observed. By direct observation, the times of negative behavior were longer in the morning 
than other times, but the difference did not reach the significance. The observed differences in ingestive behavior (eating and drinking) was agreed with Sambraus [14] and Deeming [15]. In contrast, Abdel-Hamid [1] and Wikelski et al. [16], mentioned that the feeding time was increased at mid-day than early morning and afternoon. On the other hand, the quails spent more time in flying behavior in the morning with significant differences.

Table 5: Means of quail behaviors (\% of hens in observation period) and its growth performance kept in different lighting duration

\begin{tabular}{lccc}
\hline Behaviors & $\mathbf{2 4} \mathbf{h r s}$ & $\mathbf{1 4} \mathbf{h r s}$ & $\mathbf{P}^{\mathbf{1}}$ \\
\hline Eating & $3.12 \pm 0.20^{\mathrm{a}}$ & $1.91 \pm 0.32^{\mathrm{b}}$ & 0.010 \\
Drinking & $2.98 \pm 0.23^{\mathrm{a}}$ & $1.97 \pm 0.26^{\mathrm{b}}$ & 0.017 \\
Walking & $3.30 \pm 0.14^{\mathrm{a}}$ & $2.59 \pm 0.27^{\mathrm{a}}$ & 0.041 \\
Flying & $2.77 \pm 0.37^{\mathrm{a}}$ & $1.33 \pm 0.34^{\mathrm{b}}$ & 0.018 \\
Litter scratching & $1.97 \pm 0.30$ & $1.66 \pm 0.25$ & 0.952 \\
Crouching & $2.45 \pm 0.29$ & $2.64 \pm 0.20$ & 0.589 \\
Huddling & $3.23 \pm 0.30$ & $3.32 \pm 0.29$ & 0.826 \\
Sitting & $3.73 \pm 0.26$ & $4.40 \pm 0.44$ & 0.223 \\
Idling & $1.60 \pm 0.26$ & $1.65 \pm 0.14$ & 0.864 \\
Preening & $3.01 \pm 0.31$ & $3.14 \pm 0.57$ & 0.850 \\
Dust bathing & $1.74 \pm 0.21^{\mathrm{b}}$ & $2.90 \pm 0.23^{\mathrm{a}}$ & 0.004 \\
Feather pecking & $0.05 \pm 0.02$ & $0.09 \pm 0.05$ & 0.524 \\
Aggression & $0.026 \pm 0.01$ & $0.033 \pm 0.02$ & 0.825 \\
Initial body weight $(\mathrm{g})$ & $6.06 \pm 0.23$ & $6.07 \pm 0.19$ & 0.539 \\
Final body weight $(\mathrm{g})$ & $137.97 \pm 4.43$ & $138.09 \pm 5.43$ & 0.616 \\
ABWG $(\mathrm{g})^{2}$ & $132.63 \pm 4.10$ & $132.01 \pm 5.39$ & 0.428 \\
DBWG $(\mathrm{g})^{3}$ & $4.02 \pm 0.12$ & $4.00 \pm 0.16$ & 0.221 \\
DFI & $15.06 \pm 0.25$ & $15.22 \pm 0.26$ & 0.137 \\
FCR $^{5}$ & $3.79 \pm 0.12$ & $3.90 \pm 0.19$ & 0.959 \\
\hline
\end{tabular}

${ }^{1}$ P: Probability (2-tailed). ${ }^{2} \mathrm{ABWG}$ : average body weight gain; ${ }^{3} \mathrm{DBWG}$ : daily body weight gain; ${ }^{4} \mathrm{DFI}$ : daily feed intake; ${ }^{5} \mathrm{FCR}$ : feed conversion ratio. ${ }^{\mathrm{ab}}$ Means within the same row having different superscripts were significantly different $(\mathrm{P} \leq 0.05$ and $\mathrm{P} \leq 0.01)$.

The increase of activities in the morning may be due to decrease of temperature stress. Amado et al. [17] stated that the activity of birds was high in early morning and late afternoon. Never less, the resting behavior (crouching, huddling, sitting and idling) was significantly higher at noon than other times. These results may due to mid-day have a period of quiet time in form of resting behavior [18]. In the video recording, the most recoded behaviors were significantly affected by changes in day times, which agreed with Nelson et al. [6] and Newton [19], who stated that he circadian hours have great effects on the behavior of birds in different geographical and environmental sites. While, Lincoln et al. [20] reported that circadian factors were weakly affected the behavior of birds. Ingestive, kinetic and litter scratching behaviors were higher during morning than other times that may be due to greater expression of these behaviors in the morning
[21]. The results were disagreed with Koenig [22] who detected that ingestive behavior was excessively at mid-day hours. In the current study, the quail was resting in the mid-day than other times of day, which may be attributed to the quails have a period of quiet time in form of resting behavior during the middle of the day. Furthermore, the comfort behavior (preening and dust bathing) was significantly higher at noon, afternoon and evening, respectively. These results may be due to higher resting behavior and the most of comfort behavior is in resting position. While, Abdel-Hamid [1] mentioned that, the preening and feather shaking frequencies did not affect by diurnal factors.

As general, the abnormal behaviors (aggression and feather pecking) didn't show any differences due to changes in circadian rhythm. Lighting is a powerful exogenous factor in control of physiological and behavioral processes [23]. Quails housed at 24 
$\mathrm{h}$ of light duration were significantly higher in frequencies of ingestive and kinetic behaviors than $14 \mathrm{~h}$ of light duration. In contrary, the frequency of dust-bathing was the lowest in 24 h. In this study, the significant effects of light duration in behavior were agreed with Bayram and Ozkan [24]. Never less, the results of this study revealed that light duration did not significantly affect the frequencies of other behaviors [25]. Furthermore, there were no differences in all growth performances of quails kept at different light duration. The results were disagreed with Haiming et al. [26], who found significant differences in the most of growth performances (final body weight gain, daily feed intake and feed conversion ratio). In other studies, there were significant decrease in body weight and feed conversion ratio in 24 hours duration than intermittent light [27], while Lien et al. [28] noted a positive correlation between light duration and performance in broilers.

\section{Conclusion}

From the current study, we can conclude that the changes in day times and light duration of quails'environment were associated with significantly different normal behavior, while there were no significant differences in abnormal behaviors such as aggretion and feather picking due to changes in circadian rhythm and light duration.

\section{Conflict of interest}

The authors declare no conflict of interest.

\section{References}

[1] Abdel-Hamid, E.S. (2017): Behaviour and management guide of some ornamental birds in relation to diurnal hours. Int $\mathbf{J} \mathrm{Adv}$ Res, 5(2): 2084-2090.

[2] Mohammed, H.H.; Said, E.N. and AbdelHamid, S.E. (2017): Impact of different litter materials on behaviour, growth performance, feet health and plumage score of Japanese quail (Coturnix japonica). Europ Poult Sci, 81: 719-727.

[3] Fortomaris, P.; Arsenos, G.; Angeliki, T. and Yannakopoulos, A. (2007): Performance and behaviour of broiler chickens as affected by the housing system. Archiv für Geflüegelk, 71: 97-104.

[4] Jensen, P. (2009): Diurnal time day and behaviour of poultry. PP. 129. CABI.
[5] Mohammed, H.; Grashorn, M. and Bessei, W. (2010): The effects of lighting conditions on the behaviour of laying hens. Arch Geflüegelk, 74: 197-202.

[6] Nelson, R.; Demoas, G.; Klein, S. and Kriegsfeld, L. (2002): Seasonal patterns of stress, immune function, and disease. Cambridge University Press, New York.

[7] Er, D.; Wang, Z.; Cao, J. and Chen, Y. (2007): Effect of monochromatic light on the egg quality of laying hens. Appl Poult Res, 16: 605-612.

[8] Classen, H.; Riddell, C.; Robinson, F.; Shand, P. and Mccurdy, A. (1994): Effect of lighting treatment on the productivity, health, behaviour and sexual maturity of heavy male turkeys. Brit Poult Sci, 35: 215-225.

[9] AOAC (2002): Official methods of analysis. Association official analytical chemists, Gaithersburg, USA.

[10] Dawkins, M. (2007): Observing animal behaviour. Oxford University, New York, USA.

[11] Fraser, A. and Broom, D. (1990): Farm animal behaviour and welfare. $3^{\text {rd }}$ Ed., Bailliere Tindall.

[12] SAS (2009): SAS statistical system Package-Jmp 8 User's Guide.2nd Cary, NC, SAS Institute Inc. USA.ISBN 9781-60764-301-2.

[13] Uzunova, K. (2007): Study of behaviour of broiler chickens subjected to biotic stressors. Trakia J Sci, 5(3-4): 16-18.

[14] Sambraus, H. (1994): The circadian rhythm in the behaviour of ostriches (Struthio camelus) kept in pens. Deutsche Tierarztliche Wochensch, 107(10): 339-341.

[15] Deeming, D. (1998): A note on effects of gender and time of day on the winter time-activity budget of adult ostriches (Struthio camelus) in a farming environment. Appl Anim Beh Sci, 59(4): 363-371.

[16] Wikelski, M.; Martin, L.; Robison, M.; Helm, B. and Guisnner, E. (2008): Avian circannual clocks : adaptive significance and possible involvement of energy turnover in their proximate control. Biol Sci, 363(1490): 411-423. 
[17] Amado, M.; Diego, B.; Vanner, B.; Carla, T.; Concepta, M. and Francisco, E. (2011): Behaviour of captive Ostrich chicks from 10 days to 5 months of age. R Bras Zootec, 40(7): 1613-1618.

[18] Wirminghus, J.; Downs, C.; Perrin, M. and Symes, C. (2001): Abundance and activity patterns of the cape parrot in two a fromon-tane forests in south Africa. African Zool, 36(1): 71-77.

[19] Newton, I. (2011): The ecology of bird migration patterns. London, UK. Academic Press.

[20] Lincoln, G.; Clarke, I.; Hut, R. and Hazlerigg, D. (2006): Characterizing a mammalian circannual pace maker. Science, 314: 1941-1944.

[21] McKeegan, D. and Deeming, D. (1997): Effects of gender and group size on the time-activity budgets of adult breeding ostriches (Struthio camelus) in a farming environment. Appl Anim Behav Sci, 51(1-2): 159-177.

[22] Koenig, S. (1999): The reproductive biology of Jamaica's black - billed parrot (amazona agilis ) and conservation implications. PhD, Yale University, New Heaven.

[23] Mohammed, H. (2016): Effect of different photoperiods on some maintenance behavior, external and internal egg quality traits of layers. Japanese J Vet Res, 64: S139-142.

[24] Bayram, M. and Ozkan, S. (2010): Effects of a 16-hours light, 8-hours dark lighting schedule on behavioural traits and performance in male broiler chickens. J Appl Anim Poult Res, 19: 263-273.

[25] Saiful, M.; Fujita, M. and Toshio, I. (2002): Effects of physical activities on heat production of white leghorn hens under different lighting regimes. Poult Sci, 39: 159-166.

[26] Haiming, Y.; Hao, X.; Zhiyue, W.; Jinlong, $\mathrm{X}$.; Yan, W. and Banghong, $\mathrm{H}$. (2015): Effects of intermittent lighting on broiler growth performance, slaughter performance, serum biochemical parameters and tibia parameters. Ital $\mathbf{J}$ Anim Sci, 14(4): 684-689.

[27] Petek, M.; Sönmez, G.; Yildiz, H. and Baspinar, H. (2005): Effects of different management factors on broiler performance and incidence of tibial dyschondroplasia. Brit Poult Sci, 46: 1621.

[28] Lien, R.; Hooie, L. and Hess, J. (2009): Influence of long-bright and increasing dim photoperiods on live and processing performance of two broiler strains. Poult Sci, 88: 896-903.

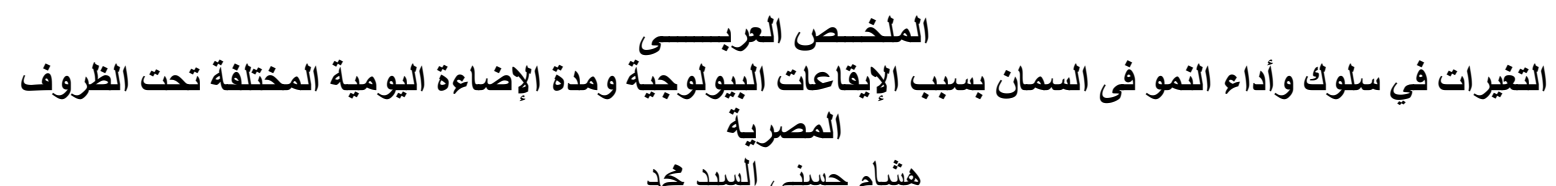

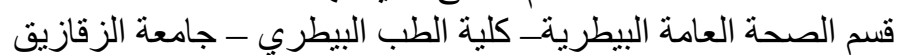

